\title{
News Construction of COVID's Crisis Management of Indonesian Government through Detik.com
}

\author{
Prayudi $^{1 *}$, Virginia Ayu Sagita ${ }^{2}$ \\ ${ }^{1,2}$ Department of Communication Science, Faculty of Political and Social Sciences, \\ Universitas Pembangunan Nasional "Veteran" Yogyakarta \\ Jl. SWK 103 (North Circle), Condong Catur, Sleman, Yogyakarta, Indonesia \\ E-mail: prayudi@upnyk.ac.id ${ }^{1 *}$; virginia@upnyk.ac.id ${ }^{2}$
}

\begin{abstract}
The COVID-19 pandemic has hit all parts of the world. This led to crises in various governments regarding how the government deals with the effects of this virus. This study aims to analyze the text of the Indonesian government's crisis communication news in the face of the COVID-19 issue in the online media Detik.com. The research method used is qualitative research with a textual analysis approach. The results showed that Detik.com reports the problem straightforwardly. Detik.com maintains a firm editorial policy and commits to presenting an even-handed and fair view of issues. Detik.com seeks to reveal how the Government responded at the start of the crisis, government policies during the crisis, and how the public responded to government policies. This research shows how online media in Indonesia constructed news on Indonesian government crisis communication in handling the COVID-19 pandemic. The substance of this research contributes in the form of new policy recommendations for the head of online media news editors to deliver news openly, straightforwardly, and critically that prioritizes social responsibility to the public. Keywords: COVID-19; Crisis Communication; Textual Analysis
\end{abstract}

\begin{abstract}
Abstrak
Pandemi COVID-19 telah melanda seluruh belahan dunia. Hal ini menimbulkan krisis di berbagai pemerintahan terkait bagaimana pemerintah menangani dampak virus ini. Penelitian ini bertujuan untuk menganalisis teks berita komunikasi krisis pemerintah Indonesia dalam menghadapi isu COVID-19 di media online Detik.com. Metode penelitian yang digunakan adalah penelitian kualitatif dengan pendekatan analisis tekstual. Hasil penelitian menunjukkan bahwa Detik.com melaporkan masalah tersebut secara lugas. Detik. com mempertahankan kebijakan editorial yang tegas dan berkomitmen untuk menyajikan pandangan yang adil dan adil dari suatu masalah. Detik.com berupaya mengungkap bagaimana respon Pemerintah pada awal krisis, kebijakan pemerintah pada saat krisis, dan bagaimana respon masyarakat terhadap kebijakan pemerintah. Penelitian ini menunjukkan bagaimana media online di Indonesia mengkonstruksi pemberitaan tentang komunikasi krisis pemerintah Indonesia dalam menangani pandemi COVID-19. Substansi penelitian ini memberikan kontribusi berupa rekomendasi kebijakan baru bagi pimpinan Redaksi berita media online untuk menyampaikan berita secara terbuka, lugas, dan kritis yang mengedepankan tanggung jawab sosial kepada publik.
\end{abstract} Kata kunci: COVID-19; Komunikasi Krisis; Analisis Tekstual

\section{Introduction}

The world is currently facing Coronavirus disease 19 or commonly abbreviated as COVID-19. COVID-19 is a contagious disease caused by a coronavirus. This disease first appeared in Wuhan, China at the end of December 2019 (Perlman, 2020). Most people infected with the COVID-19 will experience mild to moderate respiratory disease and recover without requiring special treatment. Older people and those with underlying medical problems such as cardiovascular disease, diabetes, chronic respiratory disease, and cancer are more susceptible to developing these diseases (Dennison Himmelfarb \& Baptiste, 2020). The COVID-19 virus spreads primarily through droplets of saliva or escaping from the nose when an infected person coughs or sneezes (Blocken et al., 2020). At this time, there is no specific treatment for COVID-19. However, many ongoing clinical trials are evaluating potential treatments. As of April 6, 2020, there were 1,273,712 cases of COVID-19 worldwide, with a death rate of up to 69,458 people (Table 1 ). 
Table 1. Confirmed COVID-19 Cases and Death Rates

\begin{tabular}{lrr}
\hline Country & Number of Cases & Number of Deaths \\
\hline Italy & 128,948 & 15,887 \\
Spain & 131,646 & 12,641 \\
USA & 336,830 & 9,618 \\
France & 92,839 & 8,078 \\
UK & 47,806 & 4,934 \\
Iran & 58,226 & 3,603 \\
China & 81,708 & 3,331 \\
World & $1,273,712$ & 69,458 \\
\hline
\end{tabular}

Source: (Coronavirus Update (Live), 2020)

The COVID-19 began to enter Indonesia at the end of February 2020, which means two months since the first case appeared in Wuhan, China. The President of Indonesia himself immediately announced the emergence of the first and second patients who contracted the COVID-19 on March 2, 2020.

However, the Indonesian Government had consistently denied the Coronavirus had entered Indonesia. Meanwhile, several developed countries such as Australia and America and the World Health Organization (WHO) had doubted Indonesia's ability to detect this virus and deal with patients infected with this virus. This is interesting to see how the Indonesian Government's crisis communication deals with this case.

The news media's role is very significant concerning the Government's efforts to overcome the crisis. The Government needs the media to convey the steps taken to the public. This fact is a challenge for news media institutions to keep their distance from various interests to convey information or messages independently, objectively, and value-free. Even if the mass media are to be equal, they must orient public interest. Thus, the news media reported how the Government crisis management and why news media institutions tend to report government crisis management policies with a particular orientation is exciting. In principle, the way news media report an issue cannot be separated from the actual context that the news media is trying to construct, and at the same time, this context also influences the way the media represents an issue in its reporting (Prayudi \& Hendariningrum, 2016). Thus, the research problem is how the textual analysis of the Indonesian Government's crisis communication news in dealing with the COVID-19 issue.

Research on the construction of government crisis communication news in dealing with COVID-19 is arguably still rare. Most of the research around COVID-19 has focused on the health aspect (Block et al., 2020; Gülsen et al., 2020). There's not much study that focused on the news media reporting of the COVID-19 and media in Indonesia. Some research has been conducted on COVID-19 in Indonesia, such as (Gandasari \& Dwiedinawati, 2020; Hayati \& Yoedtadi, 2020). These two studies focus on identifying news content when conveying COVID-19 pandemic information based on the frequency of appearance and news content based on social and economic issues in online news and the analysis framing ofCOVID-19 news on March 2, 2020 edition in the media of Kompas.com and Tribunnews.com. However, these two studies gave little attention to how the media reported how the Indonesian government handled the crisis. It is the gap that this research attempted to fill. 


\section{Theory of Social reality Construction}

Berger and Luckmann state that the social process is where individuals take actions and their interactions in creating a reality that is continuously shared and experienced subjectively. The substance of the theory and social construction approach to Berger and Luckmann's reality is a simultaneous process that occurs naturally through language in everyday life in a primary and semi-secondary community (Adhiarso et al., 2018). This theory and social basis approach was the modern transitional society in America in the 1960s, where the mass media has not yet become an exciting phenomenon to discuss. Further, Frans M. Parera (Peter L. Berger, 1990) explained three dialectic processes between oneself and the sociocultural world. First, externalization (adjustment), the interaction in a behavior pattern between individuals and society's social products. Human existence cannot occur in an environment of closed and motionless interiority, but human existence must always externalize itself in activities.

Second, the objectivation stage manifests itself in the available human activity products, both for the producers and others. This stage is the social interaction stage in an institutionalized intersubjective world or undergoes an institutionalization process. Objectivation can occur by disseminating opinions in the Community without facing faceto-face contact between individuals and social product creators. Third, the internalization stage is how individuals try to identify themselves with social organizations or institutions in which they are members (Bungin, 2013).

The substance of the theory and social construction approach to Berger and Luckman's reality is a simultaneous process that occurs naturally through language in everyday life in a primary and semi-secondary community (Siregar, 2019). Therefore, Peter L. Berger and Luckmann (Berger \& Luckmann, 2011) did not include mass media as a variable or phenomenon that influences reality construction theory.
The substance of the social construction theory of mass media is to cover up weaknesses and complement them by placing all the advantages of mass media and media effects on the advantages of "mass social media construction" over "social construction of reality" (Gullon, 1966). However, the simultaneous process does not occur suddenly but through several stages. They include preparing construction materials, construction distribution, and the construction of reality and confirmation.

Within the context of this study, the media construct the social reality of COVID-19 for its audience. Questions like how and why the news media construct the news in a particular way is fascinating to examine. Thus, this study aims to identify and describe the textual analysis of the Indonesian Government's crisis communication news in the face of the COVID-19 issue.

\section{Research Method}

This research used qualitative method. According to Newbold et al. (2002), an interpretive tradition becomes the basis for the qualitative research that claims that there is no objective social reality, but that reality is a social and cultural construction to be approached but never fully attainable. Qualitative research deals with the attribution of meaning to how the construction of the social world.

Textual analysis is an interpretive research method that identifies text concerning its contextual background. This approach argues that understanding text construction is inseparable from the relationship between media institutions and their social and cultural environment. In principle, analyzing media texts aims to increase our understanding of the role that the news media plays in constructing meaning in the broader culture. Analysis of media texts always starts from the text to the broader culture or audience (Cunningham \& Turner, 2020). 


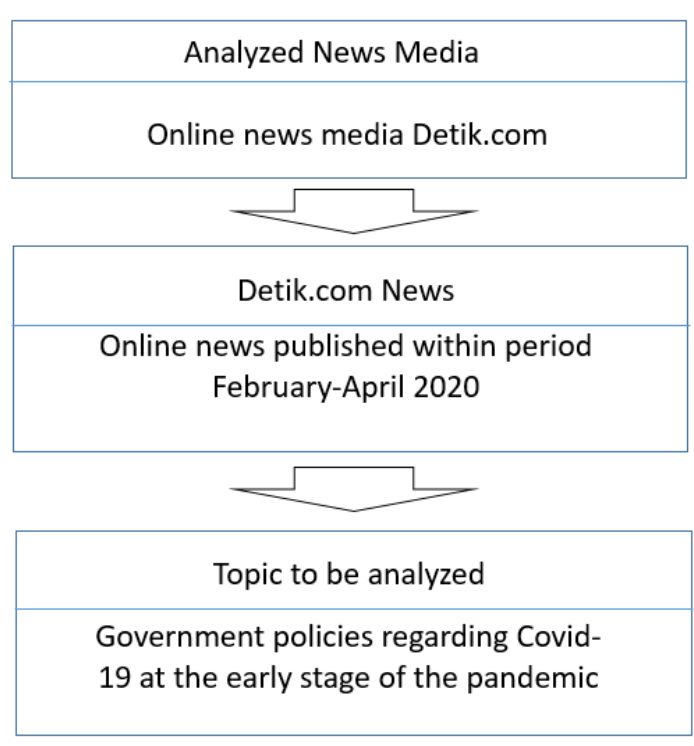

Figure 1. Steps of analysis

Source: Researcher's documents (2021)

The research subject is online news media Detik.com that has been published since 1996 and become a leading online news media in Indonesia. The research objects are news items on the Indonesian Government policies regarding COVID-19 at the early stage of pandemic (February to April 2020 period). The data gathered by compiling all relevant news items and later classified based on the dominant reported issues. The data later analyzed by questioning why and how Detik.com reported specific issues with a particular writing style. Further, the analysis was also related to the context of the news.

As part of qualitative research, data analysis in textual analysis research is highly dependent on the complexity, context, and detail of the text that represents an issue. The drawing of conclusions is in the form of a consistent description of how something works, not a mathematical calculation.

\section{Results of Research and Discussion}

Detik.com is a website that contains news and articles online in Indonesia. Detik.com is one of the most popular online media in Indonesia. The number of visitors to the website has proliferated. In July 1998, the site Detik. com received 30,000 per day hits (a measure of the number of visitors to a site) with about 2,500 users. Nine months later, in March 1999, the number of visitors Detik.com's increased sevenfold, averaging 214,000 hits per day or $6,420,000$ hits per month with 32,000 users. Three months later, the number of hits increased again to 536,000 hits per day, with users 40,000 . Shortly, page views (number of pages accessed) Detik.com has now reached 3 million per day. Currently, Detik.com is in the fourth position from alexa.com for all content in Indonesia.

Based on the number of visitors, Detik.com is one of the most popular news sites in Indonesia. It is considered as the most current and fastest online news site because news portal Detik.com in delivering news prioritizes speediness. Detik. com has several social media platforms such as Facebook, Twitter, and Instagram. With more than 16 million followers on Twitter, Detik.com is currently active on Twitter, and many of its followers often reply to tweets from the account Detik.com (@detikcom). Also, in its news portal, Detik.com provides various features such as photos, popular videos, graphic info, opinion columns for readers, and a comment column under each news. Readers can write comments and discuss with other readers in the column provided under the news after reading the news. Detik.com has the vision to be the leading news portal for Indonesians to obtain digital content and services through the internet and cellular or mobile.

In reporting COVID-19, Detik.com opens a particular link to access information about COVID-19 in Indonesia. To facilitate search, Detik.com also issues hashtags and issues news related to trends in the Community. Detik.com always provides the latest updates on the spread of COVID-19 along with patient data statistics in Indonesia. Apart from data, the portal always updates every policy enforced by the Government so that the public can immediately access it.

Based on the context of this research, there are around 34 news items related to the central Government and the Coronavirus. Detik. com pays attention to how the Government is managing the COVID-19 crisis. This seriousness 
Table 2. News items that portrayed Indonesia Government underestimate COVID-19

\begin{tabular}{ll}
\hline \multicolumn{1}{c}{ Title } & \multicolumn{1}{c}{ Publishing date } \\
\hline RI still free of the Coronavirus, 50 suspects checked, 49 free of Corona & February 72020 \\
The Government still believes that no one has been infected in Indonesia & February 102020 \\
$(7 / 2)$. RI is still safe from Coronavirus. Harvard research is a reminder to & \\
be vigilant & \\
$\begin{array}{l}\text { Vaccinologist comment on Harvard Research about the Coronavirus has } \\
\text { entered Indonesia }\end{array}$ & February 102020 \\
There is no 'Wuhan' virus in Indonesia; Previously, SARS was also & February 102020 \\
'Reluctant' to entering & \\
$\begin{array}{l}\text { Minister of Health Calling National Health Resilience an Important Role } \\
\text { in Facing the Corona Virus }\end{array}$ & February 29 2020 \\
RI: Corona is Not Dangerous, the Death Rate is Under MERS and SARS & March 3 2020 \\
\hline
\end{tabular}

Source: Primary Data Researchers (2020)

cannot be separated from the Government's response when the COVID-19 began to emerge in China and slowly spread to Asia. At the beginning of this virus's emergence, the Government tended to ignore the signs that the virus was about to enter Indonesia and even made this virus a joke. When COVID-19 finally appeared in Indonesia, the impression of being unprepared and confused when the economy did not work due to the COVID-19's impact colored the news from Detik.com. This condition has colored the analysis of this study.

Detik.com pays attention to several main issues: (i) the Government underestimates Corona, (ii) government policies in dealing with the coronavirus crisis, (iii) shifting responsibility to local governments. In particular, Detik.com pays attention to how several ministers talk to each other about the COVID-19 and do not implement one gatekeeper of information. There is a perception that some ministers talked about the virus without coordination. The choice of news orientation relates to Detik.com position as an online media representing the public's interests.

\section{The Government underestimates the COVID-19}

In a crisis, an organization, company, or country's ability to handle a crisis depends on responding to a crisis at an early stage when the crisis is still an issue or symptom, either obvious or vague. Detik.com did not explicitly state that the Government was not as severe or underestimated as the COVID-19 when it had not entered Indonesia. However, news headlines and texts citing government sources and health experts show that there is an impression that the Government is overconfident and ignorant of the signs that the COVID-19 could enter Indonesia. These are evident in some news items mentioned in Table 2. Details of news items that portrayed the Indonesia Government underestimate COVID-19 are as follow:

"Indonesia has not reported any Coronavirus cases, while according to data as of Friday afternoon (7/02), there are already 28 cases found in Singapore and 12 cases in Malaysia. Health authorities are now facing public questions about why they are so sure this potentially deadly virus is not found in Indonesia. The Ministry of Health and other related health parties had held meetings almost every day, including carrying out a Coronavirus test, and so far, no one has tested positive. Nevertheless, this sparked doubts about Indonesia's capacity to carry out virus tests and checks, even accusations that Indonesia's health workers did not follow the proper protocol." (Detik, February 7, 2020) "It has been more than a month that the Coronavirus outbreak has become a threat in various countries, and there has not been a single positive case in Indonesia. On Monday $(10 / 2 / 2020)$, the number of infected has reached 40,552 cases, and 910 died. Of course, having 
a large area is a challenge in keeping the Coronavirus from entering Indonesia. Moreover, a study at Harvard University estimated that there should have been cases reported in Indonesia. Prof. Amin also said there was a need for adequate readiness to detect patients suspected of being infected with the Coronavirus. Because the checks being carried out cannot depend solely on the officers in the airports and ports. The possibility of the virus entering Indonesia can still happen, considering neighboring countries such as Singapore and Malaysia have been infected" (Detik, February 10, 2020)

In crisis communication, the Government has encountered many communication problems in handling the COVID-19 pandemic. The Government often underestimated the urgency of spreading the virus and responded with jokes and ridicule in the early days of the virus in Wuhan and spreading to several countries. One of the cases was that the Government ignored a professor at Harvard University about the possibility that Indonesia had many positive COVID-19 cases. The Civil Society Coalition also responded that the Government's way of dealing with the virus's spread was to prevent public panic, but it did not show any real work in protecting society. The Government also seemed to limit public access to information about threats and developments in the virus's spread.

The news items above show how the Government's initial response was to the COVID-19 crisis at the beginning of its appearance. When this virus first appeared in China and spread to other neighboring countries, the Government adopted a false premise. Instead of seriously anticipating this virus's threat, the Government, through its officials and elites' statements, tended to underestimate and imply that Indonesians are immune to this virus attack. The prediction from Harvard University stated that the virus had arrived in Indonesia, was flatly rejected, and was not used to prepare a strong and effective public health policy to deal with the virus.
The Australian Government and media, for example, had cast strong criticism of the Indonesian Government's lack of preparedness, vigilance, and sensitivity to the handling of the pandemic (Jaffrey \& Jaffrey, 2020; Lindsey \& Mann, 2020). Since Australia announced the first case of COVID-19 on January 25 2020, the Government has insisted there had been no positive patient cases throughout JanuaryFebruary 2020 in Indonesia. Australia considered Indonesia should be concerned about the development of a pandemic that is not detected. James Massola (2020), a media contributor in an article entitled 'The World's Next Coronavirus Hotspot Is Emerging Next Door', explained that the development of the Coronavirus pandemic in Indonesia was called under the radar because, in just eight days, Indonesia recorded more than 1,000 new cases every day. There was also a strong suspicion that the Government manipulated COVID-19 data. This means that the number of patients exposed to the virus does not match the real situation. There is poor crisis communication in this process.

Detik.com tends to report the Government's steps that underestimate the COVID-19 outbreak fairly and balanced. The balance in reporting includes the dimensions of balance, report the whole story, objective, fairness, and accuracy. In objective journalism, reporting events must be balanced in the sense of trying to present all sides of the story. Justice means that journalists must strive for accuracy and truth in their reporting and not tilt the news so that readers draw the conclusions that journalists want. Thus, although the inclusion of Detik.com in the online news media category and has a high potential for bias, journalistic ethics are still maintained. This is inseparable from the history of Detik.com, where its founders were journalists of the Tempo Weekly News Magazine, which was banned in 1994 during the New Order era. Simultaneously, Detik.com also warned the Government of the potential for this outbreak if it entered Indonesia. 
Table 3. Title of news items that portrayed Indonesia Government policies in dealing with the COVID-19 crisis

\begin{tabular}{|c|c|}
\hline Title & Publishing date \\
\hline Expecting the COVID-19 Handling Task Force & March 152020 \\
\hline nt Jokowi's Latest Complete Statement to Fight Corona Virus & March 162020 \\
\hline Outbreak and State Responsibility & 2020 \\
\hline $\begin{array}{l}\text { Kemenparekraf opens Crisis Communication Channels for the } \\
\text { Community }\end{array}$ & March 172020 \\
\hline $\begin{array}{l}\text { Information Outbreak about One-Stop Corona, Government } \\
\text { Launches COVID-19 Site }\end{array}$ & 20 \\
\hline Corona Rapid Test Prioritized for Fighters in the Front Guard & 2020 \\
\hline rowi & 020 \\
\hline $\begin{array}{l}\text { Corona Decided to be a National Disaster, Government: Everything } \\
\text { is Transparent }\end{array}$ & April 142020 \\
\hline Tos & \\
\hline $\begin{array}{l}\text { The Long Journey Until Finally Jokowi Forbids Going Home Duri } \\
\text { the Pandemic }\end{array}$ & 2020 \\
\hline
\end{tabular}

Source: Primary Data Researchers (2020)

Detik.com focused on how government and health sources talked about this outbreak at the beginning of the virus's emergence in Wuhan and its potential to enter Indonesia.

\section{Government policies in dealing with the COVID-19 crisis}

The world was shaken by the outbreak of COVID-19, which spread rapidly throughout the world in 2020. The virus has been infecting approximately 188 countries in the world. More than 500 thousand people have died of this virus. As a global crisis and part of a developing country's category, Indonesia is likely to be severely affected by this crisis. The Government's failure in the early stages of this pandemic impacted the Indonesian economy and its people. It was evident that the Government was stuttering about the crisis.

This stuttering was evident from the mistakes made by both central and local government officials. Weak coordination between central and local governments, miscommunication between the health ministry and other agencies is evident in how the first case was announced, including violations of patient privacy rights. It seems clear that the Government tended to prioritize image over patients' benefit and broader public safety.
The Government's anticipatory attitude and quick response were not well demonstrated in a crisis that begins with symptoms like this virus outbreak. Instead, the policies that came out at the start of the crisis underestimated the virus. When the virus was finally unstoppable, and many lives were lost, what policy did the Government take? At least, Detik.com consistently reports on the steps taken by the central Government. News items explaining the Government's policy in dealing with the COVID-19 pandemic are represented in the Table 3. Details of news items that portrayed Indonesia Government policies in dealing with the COVID-19 crisis are as follow: "The Indonesian Government responds to the outbreak of the virus originating from Hubei Province, China. President Joko Widodo (Jokowi) issued Presidential Decree (Keppres) Number 7 of 2020 concerning the Task Force for the Acceleration of Handling Corona Virus. The Task Force for the Acceleration of Handling COVID-19 is subordinate and responsible to the President. Head of the National Disaster Management Agency, Lt. Gen. Doni Monardo, was appointed Chief Executive. The formation of the task force was due to the transmission of COVID-19 to Indonesia. To accelerate COVID-19 crisis management, fast, precise, focused, integrated, and synergistic steps 
are needed between ministries/agencies and local governments. Chief Expert of the Presidential Staff Office, Donny Gahral Adian, said the Government formed a task force team to take quick and coordinated steps to overcome the COVID-19 pandemic. Donny said that this task force would also establish relationships with research institutes and universities. The Task Force for the Acceleration of Handling COVID-19 was also a response to WHO's request for the Indonesian Government to announce the Corona national emergency immediately. The Presidential Palace said that the Task Force's formation for the Acceleration of Handling COVID-19 improved handling the Coronavirus outbreak. Presidential Spokesman Fadjroel Rachman said the formation of Task Force for the Acceleration of Handling COVID-19 was to sharpen the Government's coordination capabilities in dealing with this outbreak. Regarding WHO's suggestions, Fadjroel said that the Indonesian Government had taken steps as requested" (Detik, March 15, 2020)

"I need to emphasize first that the lockdown policy at both the national and regional levels is the central Government's policy; the regional Government should not take this policy, and so far, we have not thought about the lockdown policy. Right now, the essential thing is how we reduce the mobility of people from one place to another to maintain a distance and reduce crowds who carry a greater risk of the spread of COVID-19. We need to intensify policies on learning from home, working from home, and worshiping at home to reduce the spread of COVID-19 while maintaining services to the Community, be it matters of basic needs, health services, and other public services. The central and local governments must provide clean public transportation. This policy must be implemented in transportation mode, namely trains, city buses, MRT, LRT, Trans buses, which are essential to reduce crowd levels, queues, and people's density to keep our distance from one another. Second, all significant policies at the regional level related to COVID-19 must first be discussed with the central Government. I asked the regions to consult with the relevant ministries and the COVID-19 task force to facilitate communication. Third, to avoid confusion of information conveyed to the public, I also ask that the COVID-19 Task Force be the only reference for information to the public" (Detik, March 16, 2020)

"President Joko Widodo (Jokowi) stated that it is now necessary for the civil emergency policy to deal with the Coronavirus (COVID-19) pandemic. However, this consideration was rejected by several parties, including the National Human Rights Commission and the civil society coalition, because it was considered that the civil emergency was more focused on the security aspect, not health. Jokowi believes that social policy restrictions need to be implemented on a large scale. Physical distancing or maintaining physical distance must be applied in a firm, disciplined, and effective manner. All of this is to prevent the spread of COVID-19. The Civil Society Coalition for Security Sector Reform has a different opinion from the President in dealing with the Corona pandemic. The Government should refer to Law Number 24 of 2007 concerning Disaster Management and Law Number 6 of 2018 concerning Health Quarantine as a legal umbrella in overcoming the Corona pandemic" (Detik, March 31, 2020)

One step in the Jokowi administration's crisis management should be appreciated from the three news items above, namely the COVID-19 Task Force formation. The policy for forming the Task Force for the Acceleration of Handling COVID-19 is stated in Presidential Decree (Keppres) Number 7 of 2020. This Presidential Decree was signed by Jokowi on Friday $(13 / 3 / 2020)$ when the Government announced the number of positive cases in Indonesia had jumped to 69 cases, with four people passed away.

There are five Task Force tasks for the Acceleration of Handling COVID-19 in this Presidential Decree. First, establish and implement an operational plan to accelerate the handling of COVID-19. Second, coordinate and control the implementation of activities to accelerate the handling of COVID-19. Third, supervise the implementation of the accelerated 
handling of COVID-19. Fourth, mobilizing resources for the implementation of activities to accelerate the handling ofCOVID-19. Fifth, report the implementation of the accelerated handling of COVID-19 to the President and Director.

Efforts to reduce the movement of people both within one region and between regions should be appreciated. Even though it prohibits the lockdown, the effort to prohibit going home before Eid due to the potential for transmission of this disease from homecoming people is an example of a tactical policy that needs to be carried out. Early detection as a form of surveillance was carried out, especially for 19 areas with direct access to China, namely Jakarta, Padang, Tarakan, Bandung, Jambi, Palembang, and Denpasar Surabaya, Batam, and Manado. Another thing that should be appreciated is the policy of studying from home, working from home, and praying at home to reduce the spread rate of COVID-19.

Detik.com noted that the formation of the task force was after WHO suggested that Indonesia created a Task Force on Coronavirus crisis management. The news media attempted to inform the public that this policy was not entirely a government initiative. This was evident from the date of the task force formation, which was 12 days after the Government announced the first case of the outbreak of COVID-19 in Indonesia. Simultaneously, news like this is also a way of Detik.com's conveying criticism to the Government. In addition to reporting the Government's policies, Detik.com journalists also adopted the writing technique to report the policy's reasons. Even though it did not seem to lead the reader, the news media tried to explain to readers how the Government worked in dealing with the COVID-19 crisis.

In a crisis context, the level of response to a crisis determines whether organizations can manage it well or not. A crisis can be defined as an unstable state and can disrupt organization activities. However, if managed properly, the crisis that was a threat can become an opportunity to show the company's performance to the corporate public. Organizations that think about the negative impact a crisis might cause will try to prepare themselves before a crisis occurs (Prayudi, 2016). Another form of how Detik.com criticized the Government in handling the crisis was Jokowi's plan to implement a civil emergency. Jokowi delivered a speech through a limited meeting regarding large-scale social restrictions and physical spacing to reduce the rate of transmission of COVID-19 in Indonesia. The implementation of these two policies was based on civil emergency status, which was regulated in Government Regulation in Lieu of Law (Perppu) No. 23 of 1959 concerning the State of Danger.

The President's civil emergency status policy had drawn negative responses in the Community. One of them, as expressed by the Civil Society Coalition, that the Government should determine the status of public health emergencies, as referred to in Law Number 6 of 2018, and place the highest authority in efforts to deal with COVID-19 in the health authorities, instead of of a civil emergency condition.

Implicitly Detik.com depicts Jokowi lack of understanding in policymaking and several communication problems within the Jokowi administration. A few days later, the Presidential Spokesperson and the Coordinating Minister for Politics, Law, and Human Rights attempted to clarify the speech.

Speaking about the civil emergency option as an action to deal with the spread of COVID-19, there is a misconception of implementing civil emergency in dealing with dangerous situations. It is noteworthy that Indonesia itself already has Law Number 24 of 2007 concerning Disaster Management, where if we see the spread of COVID-19 as a disaster, it can be said to be a non-natural disaster, which includes the spread of disease outbreaks. 
Table 4. Title of News Items that Portrayed Public Response to Government Crisis Communication

\begin{tabular}{|c|c|}
\hline Title & Publishing date \\
\hline the Corona Outbreak and State Responsibility (17/03), & March 152020 \\
\hline $\begin{array}{l}\text { Facing the Corona Outbreak in RI, Jokowi-Terawan communication } \\
\text { is bad }(12 / 04) \text {, }\end{array}$ & March 162020 \\
\hline People Start Panic. Government Failed to Handle Corona! (12/04), & March 172020 \\
\hline $\begin{array}{l}\text { Unpad-UP Research: } 72 \% \text { of Respondents Value the Government is } \\
\text { Overwhelmed by Corona }(21 / 05)\end{array}$ & March 172020 \\
\hline
\end{tabular}

Source: Primary Data Researchers (2020)

On this case, Law Number 24 of 2007 has separated disasters to determine civil emergency status where a disaster has its status determination and handling. The Law does not mention civil emergency as part of the disaster emergency status. The Law is also a specialist rule in national disaster management. So, it would be a mistake to determine a civil emergency status to handle the COVID-19 pandemic. The Government should remember that Indonesia has a Disaster Management Law in handling natural and non-natural disasters (BEM Unpad, 2020).

Generally, Detik.com reports that the policies taken by the Jokowi administration in dealing with the Coronavirus pandemic in Indonesia were responsive sporadic. It means that the policies taken seem not to control the crisis and the policies that need to be prepared to prevent the crisis from developing. The indecisiveness can be seen from the encouragement of the World Health Organization for the formation of a task force, plans to implement a civil emergency, and the existence of a ministry that talked about crisis communications that were not its domain.

\section{Public Response to Government Crisis Communication}

A crisis is interpreted as something that comes as a surprise and presents a threat to the organization, company or industry, and their public, products, services, or the good name they already have. As a threat, the crisis must be handled quickly so that the organization can normally run again. The crisis put the company appearance under public judgment. The public usually requires an immediate response from the organization (Prayudi, 1998). Three conditions are common in a crisis. These include unpredictable elements, insufficient information, and the dynamics are so fast (Argenti, 2008).

There is an increased flow of information, and the communication system is unstable in a crisis. Also, crisis communication emotional content is very striking, and the network between interpersonal communication and media communication is also essential. In the age of the internet, human attachments extend beyond mass media and to social networking sites. Interpersonal communication networks will also improve through these social networks. There are three main principles in crisis communication: conveying messages quickly or immediately conveying messages, consistent and open (Coombs, 2006). This seems to have not appeared in the Government's crisis communication and is visible from several detik.com news items such as follows.

Details of news items that portrayed public response to government crisis communication are as follow: "The Institute for Development of Economics and Finance (Indef) conducted a public survey regarding the Government's performance in dealing with the Coronavirus. Indef highlighted the negative sentiments directed at President Joko Widodo and Minister of Health Terawan Agus Putranto. Senior economist Indef Didik Rachbini 
explained, of the 135,000 people surveyed, $66.28 \%$ showed negative responses. Meanwhile, the positive response was only $33.72 \%$. That negative sentiment to the Government is very high, around $66.28 \%$. So we suggest that the Government should raise positive sentiment in an honest, transparent way, then earnestly and not underestimate it," Didik said via teleconference, Sunday $(5 / 4 / 2020)$. This survey used data collected from Twitter, which talked about the Coronavirus as many as 145,000 people, and the six largest online news portals. The data was collected from January to March 2020. Didik also explained that people tend to be dissatisfied because communication between governments regarding the handling of the Coronavirus is horrible. The ones who get the most negative sentiments from the public are Minister of Health (Menkes) Terawan and President Joko Widodo (Jokowi). The President and the Minister of Health have a difficult time in communication. That is the first thing we see from this research. These two people have the highest negative sentiments. This must be corrected, he said. Also, the Government is considered to have underestimated the Coronavirus from the start. Thus, there is no proper preparation in dealing with this pandemic. This is a reflection of the Government because, from the beginning, it was joking. For example, 'it is impossible for Indonesia to get it if it uses wild horse milk.' So the communication from the government ranks is of low quality, he said" (Detik, March 15 2020)

"Amid the Coronavirus that is increasingly spreading in Indonesia, many people have complained about their economic difficulties. Especially for informal workers who have lost their income sources, formal workers are overshadowed by layoffs due to the business weakening. The Government itself has claimed to have a myriad of solutions to overcome the economic downturn in society. The establishment of social safety net programs for small communities and pre-work cards for victims of layoffs are evident. However, the Community did not feel the impact of these programs. According to economic researcher Indef Bhima Yudhistira, the Government is not ready for these programs, and data collection is the main problem.
Bhima assessed that the Government had from the beginning underestimated the economic impact of the Corona outbreak. Thus, assistance programs like this appear to have been carried out too hastily and have not been adequately prepared. In fact, since last January, when the Coronavirus has not been proven to have infected Indonesia, data collection on recipients of various types of government assistance programs should have been carried out. However, it was neglected" (Detik, March 17 2020)

"Padjadjaran University (Unpad) and Pancasila University (UP), in collaboration with the Technische Universtät (TU) Ilmenau in Germany, researched community perspectives regarding the conditions of the Coronavirus crisis (COVID-19) in Indonesia. The results of the research stated that $72 \%$ of respondents thought the Government was overwhelmed with Corona. In a press release received on Thursday (21/5/2020), the purpose of this study is to see public opinion about the Corona crisis in general and how the use of media in society can influence the formation of perceptions about the crisis. This study used a nationally representative survey method. The data collection was carried out through a digital application carried out by Jakpat Mobile Online Survey Indonesia. The data collection period was carried out on April 27 -18 May 2020 and reached 1,100 respondents from all provinces in Indonesia. Research shows that $70 \%$ of respondents said they were satisfied with the central Government's policies in overcoming the Corona problem. This proportion is likely to change since $72 \%$ of respondents believe the Government is overwhelmed with Coronavirus." (Detik, March 17 2020)

Based on the three news items above, Detik.com highlighted the Government's crisis communication. Both the President and his ministers, the ineffective crisis solution, and the public perception that the Government is overwhelmed in overcoming the corona crisis. Detik.com conducted reporting on this issue to see how the public perceives the Government's crisis management and communication 
performance. Detik.com did this by reporting the results of a survey from several credible institutions and universities that surveyed the satisfaction of the performance of the Jokowi regime in managing the COVID-19 crisis. Detik. com provides readers with an opportunity to judge whether what the Government is doing in the crisis is acceptable. From the perspective of Detik.com, the public has the right to interpret news freely. As Allan (2010) says, "Journalism has an important mission to ensure that members of society can take advantage of the various 'marketplaces of ideas' to defend and challenge their feelings about the world around them".

This could be Detik.com's way of criticizing the Government. Detik.com tries to play its role as the fourth pillar of the country with a solid and clear editorial policy or the fourth estate. As Prayudi states (2010): "Newsmedia works through the dissemination of messages to the public. In countries where democratic values are upheld, and people have the right to seek, own, and disseminate information, the responsibility to inform the public has made the press freely inform news without fear of being banned by the Government. While the media seeks to inform its public and provide the sort of democratic Fourth Estate functions described by Thomas Carlyle, it has also been subject to the interests of cultural and political contentions." The news writing technique used by Detik.com showed that this media criticizes the Government indirectly. It uses sources or secondary data from second parties. The use of standard journalistic language that does not appear to be sharply critical is the hallmark of Indonesian journalism, which means that written news still considers the public interest as a form of social responsibility. Detik.com can also play a role as the fourth estate. Another thing is that Detik.com can show that it is trying to be neutral from political interests. The Government has made various efforts to handle the crisis deserves appreciation, but the way the Government has handled the crisis also needs to be criticized. Jokowi, as President, has not shown strong leadership in a crisis. The communication was not firm and impacted the COVID-19 crisis, which took a long time to handle.

The essential communication elements should not be viewed as planned, delivered, and then completed activities. Communication is a process to achieve mutual understanding, in which communicators and audiences create, share, and exchange thoughts, opinions, and information. Effective communication requires an understanding of the communicator, audience, goals, messages, and the most effective ways to achieve the desired results. It is also a twoway activity, listening to the audience, and acknowledging their concerns. Well-executed and properly executed communication, integrated into every crisis and emergency response stage, can help alleviate the dreaded thing, namely suffering and death. Being able to communicate effectively is an essential part of every leader's job.

The COVID-19 pandemic has shown the Indonesian Government's unpreparedness in facing the crisis. This unpreparedness was evident from the disorganized governance used in handling this deadly outbreak. Government officials tend to underestimate and denigrate. The statements of several government officials, such as the health minister and Coordinating minister of politics, law and human rights, and vice president, are proof of this.

The study shows the COVID-19 coverage was more massive than Ebola. As proposed by social construction theory, the news media helped construct the way people think of the COVID-19 pandemic and how the government handled the crisis. The news media under study shows that the government had not anticipated the COVID-19 pandemic correctly, resulting in a weak response to the crisis. The rumors circulating in the Community more or less reflect how the Government anticipates public concerns 
regarding COVID-19. Government public communication has not effectively disseminated monitoring efforts, the latest developments, and prevention efforts that the Community can take. Information disclosure is the key to building public trust in the Government and reducing the risk of misinformation and chaos in society.

The media policy in deciding which news should be published also contributes to shaping the public conversation. The media can direct the things that should be of mutual concern. Almost all the media talk about Coronavirus every day. One thing that is missing in the national news media coverage is the spread of this virus, which has a global impact, where one country's weaknesses can affect other countries. The pressure on society and the Government is still lacking. Several media in other countries provide more information and different perspectives in reporting on the COVID-19, such as humanizing victims and the existence of an emergency case financing scheme. Meanwhile, local media still cover more basic information about the number of sufferers, even love for the location between quarantined Indonesians. Unfortunately, the local media often emphasizes officials" opinions who are "eccentric" or clickstanza rather than presenting essential facts and information that is released (Herlinda, 2020).

The Government already has a communication and information center based at the Presidential Staff Office. However, there appears to be no effective risk communication strategy involving various sectors. The media plays a crucial role in conducting risk communication. Unfortunately, the Government has not effectively provided detailed and routine information for the media to report to the public, so that the news and information obtained by the public are confusing.

Detik.com represents how the Crisis government uses an open, straightforward, and critical reporting style that is a new feature of the Indonesian press in the "reformation" era. In this regard, Detik.com contributes directly to the fourth function of an effective secular government following the pluralist ideals of the Indonesian Constitution and its supporting framework, Pancasila. Through this representation, Detik.com can show its social responsibility to the public. This daily newspaper has become a medium, as introduced by Jurgen Habermas, a communicative public space where all citizens have access and freedom to express and publish their opinions on issues of critical social and political interest.

Crisis communication also means humanizing people's misery and avoiding communications that corner, discriminate against, and create stigma. In epidemic and emergency case management, the media can help create better news and public perceptions to minimize adverse impacts and carry out management and distribution of information more carefully.

In the case of COVID-19, the media role is crucial to continue to pressure the Government to make optimal efforts to detect, monitor, and manage case handling as a whole. So far, the Government has been slow to respond and seems to be taking it easy to the point where it finally made unnecessary comments. Instead of taking in unnecessary comments, the media can become a forum for people's aspirations to demand that the Government do a better job because the prevention and treatment of infectious diseases for 260 million people cannot be done just by saying prayers.

\section{Conclusion}

As an online news media institution published by former journalists from credible media banned in the New Order era, Detik. com has turned into high-quality online news media with a distinctive Indonesian perspective. In connection with the representation of the Government crisis communication in managing the COVID-19 pandemic, Detik.com reports the issue straightforwardly. With a solid editorial stance, Detik.com is impartial and presents a balanced perspective following its editorial policies and fourth pillar media standards. 
Under this perspective, Detik.com seeks to reveal how the Government responded at the beginning of the crisis, government policies in dealing with crises, and how the public responded to government policies in managing crises. News representation of these three issues is constructed with a distinctive approach to Indonesian journalism, namely, providing understanding to the public, supporting better development pathways, and politely delivering criticism.

Detik.com generally describes the Government tends to underestimate the spread of COVID-19 in Indonesia by assuming this virus will not enter Indonesia and ignoring research results from the world-leading universities. The comments of ministers who looked for a stage is another concern for Detik.com. After encouragement from WHO, a COVID-19 task force formation shows how the Government seems confused about managing the COVID-19 crisis. Despite appreciating several sporadic government policies, Detik.com still criticizes the Government for its attempt to implement a civil emergency. Although a presidential spokesman later revised it, the Government lack of understanding of the health pandemic crisis rules.

Detik.com conveyed these issues through an open, direct, and critical reporting style, a new feature of the Indonesian press in the era of 'reform' (reform). Through this representation, Detik.com can show its social responsibility to the public. This daily newspaper has become a medium, as introduced or a communicative public space where all citizens have access and freedom to express and publish their opinions on issues of critical social and political interest.

This shows that communication governance should be a serious concern. The Government communication policy should pay attention to various aspects, especially relating to conveying the policy for handling the COVID-19 pandemic to the public. More is explicitly governance in conveying information about health protocols. The form of delivery, media to convey information, and audience behavior are some factors to consider. The substance of this research contributes in the form of new policy recommendations for online media news leaders to deliver news openly, straightforwardly, and critically that prioritizes social responsibility to the public.

\section{Acknowledgment}

The authors would like to thank the Institute for Research and Community Service at Universitas Pembangunan Nasional Veteran Yogyakarta, Indonesia, for providing fund for this research.

\section{References}

Adhiarso, D. S., Utari, P., \& Hastjarjo, S. (2018). The Influence of News Construction and Netizen Response to the Hoax News in Online Media. Jurnal The Messenger, 10(2), 162-173. https://doi. org/10.26623/themessenger.v10i2.782

Allan, S. (2010). News culture. McGraw-Hill Education (UK). Argenti, P. A. (2008). Corporate Communication. https://b-ok.lat/book/5471163/b6aa78

Berger, P. L., \& Luckmann, T. (2011). The Social Construction of Reality: A Treatise in the Sociology of Knowledge. Open Road Media.

Block, R., Berg, A., Lennon, R. P., Miller, E. L., \& Nunez-Smith, M. (2020). African American Adherence to COVID-19 Public Health Recommendations. HLRP: Health Literacy Research and Practice, 4(3), e166-e170. https:// doi.org/10.3928/24748307-20200707-01

Blocken, B., Malizia, F., van Druenen, T., \& Marchal, T. (2020). Towards aerodynamically equivalent COVID-19 $1.5 \mathrm{~m}$ social distancing for walking and running. 12. Bungin, B. (2013). Penelitian Kualitatif: Komunikasi, Ekonomi, Kebijakan Publik dan Ilmu Sosial Lainnya. Kencana. https://openlibrary. telkomuniversity.ac.id/pustaka/14157/penelitian-kualitatif-komunikasi-ekonomi-kebijakan-publik-dan-ilmu-sosial-lainnya.html 
Coronavirus Update(Live):92,718,866Casesand 1,984,911 Deaths from COVID-19 Virus Pandemic - Worldometer. (2020). https://www. worldometers.info/coronavirus/\#countries

Cunningham, S., \& Turner, G. (2020). The media and communications in Australia. https://www.taylorfrancis . com/books/9781003118084

DennisonHimmelfarb,C.R.,\&Baptiste,D.(2020). Coronavirus Disease (COVID-19). The Journal of Cardiovascular Nursing. https:// doi.org/10.1097/JCN.0000000000000710

Gandasari, D., \& Dwiedinawati, D. (2020). Content analysis of social and economic issues in Indonesia during the COVID-19 pandemic-ScienceDirect. https://www.sciencedirect.com/science/article/pii/S2405844020324427

Gullon, J. (1966). The social construction of reality: A treatise in the sociology of knowledge. https://www.academia.edu/1616045/ The_social_construction_of_reality_a_ treatise in the sociology_of_knowledge Gülsen, A., Yigitbas, B. A., Uslu, B., Drömann, D., \& Kilinc, O. (2020). The Effect of Smoking on COVID-19 Symptom Severity: Systematic Review and Meta-Analysis. https://www. hindawi.com/journals/pm/2020/7590207/

Hayati, H. N., \& Yoedtadi, M. G. (2020). Konstruksi Berita COVID-19 Di Kompas.com dan Tribunnews.com. Koneksi, 4(2), 243250. https://doi.org/10.24912/kn.v4i2.8114

Herlinda, O. (2020). Menimbang Peran Media dalam Menghadapi Epidemi-Remotivi. https://www.remotivi.or.id/amatan $/ 575 /$ menimbang-peran-media-dalam-menghadapi-epidemi

Jaffrey, S., \& Jaffrey, S. (2020). Coronavirus Blunders in Indonesia Turn Crisis Into Catastrophe. Carnegie Endowment for International Peace. https:// carnegieendowment.org/2020/04/29/ coronavirus - blunders - in - indonesia-turn-crisis-into-catastrophe-pub- 81684
Lindsey, T., \& Mann, T. (2020). Indonesia was in denial over Coronavirus. Now it may be facing a looming disaster. The Conversation. http://theconversation.com/indonesia-was-in-denial-over-coronavirus-now-itmay-be-facing-a-looming-disaster- 135436

Massola, J. (2020). Indonesia: The world's next coronavirus hotspot is emerging next door. https://www.smh.com.au/world/asia/ the-world-s-next-coronavirus-hotspot-isemerging-next-door-20200619-p5549q.html

Newbold, C., Boyd-Barrett, O., \& Bulck, H. van den. (2002). The media book. Arnold; Oxford University Press.

Perlman, S. (2020). Another Decade, Another Coronavirus. New England Journal of Medicine, 382(8), 760-762. https://doi.org/10.1056/NEJMe2001126 Prayudi, P. (1998). Strategi Komunikasi Organisasi dalam Menghadapi Krisis. Paradigma: Jurnal Masalah Sosial, Politik Dan Kebijakan, 2(6), 31-42. Prayudi, P. (2010). Terror in Indonesia: Terrorism and the representation of recent terrorist attacks in three Indonesian news publications within a context of cultural and social transition (Doctoral dissertation, $\mathrm{PhD}$ thesis, Royal Melbourne Institute of Technology, Melbourne). Prayudi, P. (2016). Manajemen Isu dan Krisis: Vol. (Issue). LPPM UPN 'Veteran' Yogyakarta. http://eprints.upnyk.ac.id/15294/ Prayudi, P., \& Hendariningrum, R. (2016). Textual Analysis of the Jakarta Post Online Representation of Presidential Candidates in Indonesia Humaniora. https://journal.ugm. ac.id/jurnal-humaniora/article/view/22288 Siregar, Z. (2019). Social Construction Of Mass Media. Jurnal Sains Sosial: Malaysian Journal of Social Sciences, 3(1), 51-58. 